\title{
В ПАМЕТ НА ДОЦ. ГУДЕВА
}

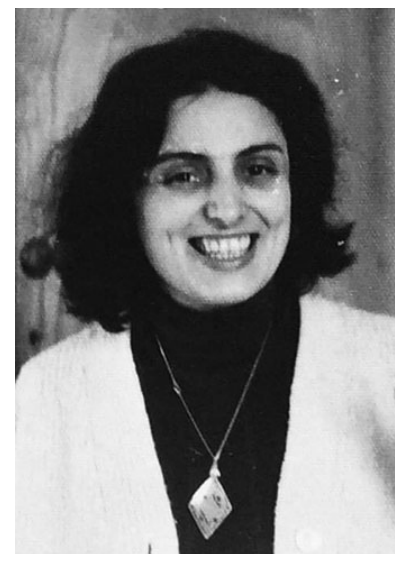

На 24.04.2020 г. почина уважаваната от всички нас невроофталмоложка доц. д-р Теодора Константинова Гудева-Попниколова.

Тя е родена на 11.12.1936 г. в София. През 1954 г. завършва с отличие 18 смесено среднообразователно училище в София, а през 1961 г. завършва медицина в Медицинския факултет при Висшия медицински институт в София. През 1966 г. придобива специалност „Очни болести“. През 1986 г. защитава успешно дисертация, след което ѝ е присъдено научно звание „старши научен сътрудник втора степен“. В периода 17.09.1962-01.07.1966 г. работи като ординатор в Общинска болница, гр. Петрич. През 1966 г. започва работа в Катедрата по очни болести във ВМИ - Александровска болница. По-късно работи в Неврологична клиника към Катедрата по неврология на Медицински факултет в София.

Доц. д-р Теодора Константинова Гудева-Попниколова е първият профилиран български невроофталмолог. През 70-те години на 20-и век работи заедно с редица известни български неврохирурзи, създатели на модерната неврохирургия в МФ в София и в България - Ф. Филипов,

С. Габровски, С. Унджиян, М. Каменова, Л. Карагьозов, П. Вецка, А. Къркиселян и др. Завежда сектор „Офталмоневрология“ при Катедрата по неврология в Медицински университет - София.

Има над 40 научни публикации; съавтор е на 3 ръководства по очни болести; на ръководство по неврология (Обща неврология под редакцията на проф. д-р С. Янчева), 1988 г.; Офталмоневрология, 1999 г., (под редакцията на проф. д-р Н. Константинов) и др. Член на дружествата на офталмолозите и невролозите.

Лекувала е стотици хора, спасявала е човешки живот, обучила и вдъхновила десетки лекари и специалисти.

През 2007 г. по повод 90-годишнината на Медицински факултет в София е наградена с юбилеен медал за дългогодишна преподавателска и научна дейност, като лекар и медик, допринесъл за утвърждаване на високия авторитет на Факултета през годините.

Тя е пример за скромен, лишен от суета и кариеризъм лекар. Беше изключително отдадена на работата си и я вършеше с много любов и отговорност към хората. Като момиче е свирела прекрасно на пиано и близките ѝ са очаквали, че ще се занимава професионално с музика. Била е типичен човек на изкуството, отличаваща се с ранимост и чувствителност. Записва медицина. Работи усилено. Консултира и в провинцията. Здравето ѝ започва да се руши постепенно от натоварването и стреса, но тя не се предава. Има мисия и я изпълнява с достойнство и със сърце. Обучава много офталмолози. Беше изключително толерантна, вдъхновяваща, отдадена и майчински настроена към младите хора. Пациентите я боготворяха заради човешкото ѝ отношение, отговорността и ангажираността към здравето им. Съпругът ѝ е проф. д-р. Серафим И. Попниколов, един от създателите и дългогодишен ръководител на интензивното кардиологично отделение в Трета градска болница в София. Доц. Гудева е майка на две деца - син и дъщеря. Когато се пенсионира, се посвети на отглеждането на четирите си внучки - София, Теодора, Йоана и Мария, които рано загубиха майка си. Днес момичетата са изградени личности, завършили елитни гимназии. Владеят езици. Всички са с висше образование. Тя живя един много достоен живот, отдаден на семейството и на професията си до сетния си дъх.

Б. Самсонова 